Helgoländer wiss. Meeresunters. 17, 200-208 (1968)

\title{
'The influence of human activities on breeding and spawning of littoral marine bottom invertebrates
}

\author{
Simon A. Mileikovsky \\ Institute of Oceanology, Academy of Sciences of the USSR, Moscow, USSR.
}

\begin{abstract}
KURZFASSUNG: Der Einfluß menschlicher Einwirkungen auf Fortpflanzung und Laichen litoraler mariner Bodenevertebraten. Die Einflüsse menschlichen Wirkens auf die Laich- und Fortpflanzungstätigkeit mariner, litorallebender Bodenevertebraten werden an Hand von Literaturbearbeitungen und eigener Forschungsergebnisse erörtert. Besondere Berücksichtigung erfahren dabei die Erwärmung lokaler Bereiche durch das Kühlwasser von Kraftwerken, chemische Wasserverunreinigung, Schiffsverkehr und größere Flüsse. Als biologische Konsequenzen, die insbesondere in flachen, teilweise eingeschlossenen Meeresgebieten ein starkes Ausmaß erreichen können, werden angeführt: (1) Veränderungen hinsichtlich des Zeitpunkts und jahreszeitlichen Ablaufs des Laichgeschäfts einheimischer Populationen; (2) Einwanderung tropischer und subtropischer Arten in lokal erwärmte Gebiete; (3) Stimulation der Gametenausschüttung außerhalb der normalen Laichzeiten; (4) Veränderungen in der normalen Sukzessionsfolge lokaler Planktonpopulationen; (5) Quantitative und qualitative Verschiebungen im planktonischen Ơkosystem.
\end{abstract}

\section{INTRODUCTION}

Human activities tend to concentrate along marine shores. Maintenance of harbours, industrial - and sometimes also agricultural or food developing - plants, villages, towns and cities discharging their domestic wastes into the sea - such human activities increase progressively all over the world: they exert an ever growing influence on nearshore marine waters and the organisms contained therein.

Among the major polluting components one may distinguish: oil products, chemical wastes, domestic sewage, radioactive substances and heated effluents from cooling systems of industrial installations and power stations. All these pollutants tend to enrich the littoral waters with foreign organic and inorganic components, thus influencing - as special investigations have shown - the endemic bottom invertebrate fauna, modifying its composition, patterns of distribution, biological cycles and the activities of individual species.

In view of the importance of these modifying effect, recent scientific efforts have resulted in the creation of a new branch of Oceanography, the "sanitary marine hydrobiology" or "medical oceanography". The rapidly increasing amount of special literature on this subject has been summarized repeatedly in review articles. Important 
contributions have been written by ReISH (1955, 1957a, b, 1960, 1961 and others), Lyn \& Won TAK Yong (1960), MacNulty et al. (1959), Loosanoff (1959), Alfimov (1959), Yakovenko (1959), Mironov (1966), Stroganov (1964) and others.

NAYLOR $(1965 \mathrm{a}, \mathrm{b})$ reviewed literature concerning the effects of heated effluents on marine and estuarine organisms. On the basis of his own and literature data he showed that heating of sea-water by such effluents may influence the breeding of littoral bottom invertebrates. Our own summarizing and analyzing of literature showed also other components of human activities on the sea shores influence, in some situations, the breeding and the spawning of littoral bottom invertebrates.

Marine littoral waters consist of a variety of very specific biotopes. It is known (Thorson 1946, 1950, 1952, Mileikovsky 1965) that an overwhelming majority of marine bottom invertebrates with pelagic development live on the shallow shelf and that in littoral marine plankton of all parts of the ocean, with the exception of the regions from highest latitudes (in tropical and subtropical waters all year round, in temperate waters from early spring to autumn), the larvae of bottom invertebrates are very numerous and form the important component of zooplankton.

These larvae establish a system of interrelations with holoplankton forms - for example by severe competition for algal food and thus become components of preypredator chains (as prey or predator). As a result of these interrelations between meroand holoplankton in littoral zones characterized by large quantities of pelagic larvae of bottom invertebrates, seasonal patterns and periodicity of breeding or spawning of such invertebrates determine the seasonal changes in larval abundance which may affect the whole system of planktonic biocoenoses, its species composition and biological activities (MnterkovskY 1960).

Because of this lability of littoral waters the additional influence of human activities is of special interest, both as a contribution to pollution research and as a basis for the study of all factors influencing the biology of neritic marine plankton and the biology of the marine littoral zone as a whole. Hence I have undertaken an attempt to summarize and analyze information from literature which deals specially with the influence of human activities on the breeding and spawning of marine littoral bottom invertebrates (see also MLeErovsky 1965).

\section{HEATED EFFLUENTS FROM COOLING SYSTEMS OF POWER STATIONS AND INDUSTRIAL PLANTS}

The influence of heated effluents on the breeding of littoral marine and estuarine bottom invertebrates has been, as mentioned before, reviewed by NAYLOR (1965a, b). In spite of that we want to discuss it here again briefly on the basis of the newest data only touched upon by NAYLOR.

Heated effluents of industrial origin are being discharged into the sea in many regions of South England and Wales, for example, in Southampton harbour and in nearby Marchwood, in Portsmouth harbour, and in Swansea docks (Ansell 1963, 
Raymont \& Carrie 1964, Stubbings \& Houghton 1964, Naylor 1965a, b and others).

How strongly such heated effluents may change the temperature regime may be exemplified by the Marchwood area where heated waters from the cooling system of a power station are discharged into the sea. Before the erection of this station (in the middle of the nineteen fifties), minimum water temperature was in winter $1^{0}$ to $2^{\circ} \mathrm{C}$ (in 1954 the temperature was $-1^{\circ} \mathrm{C}$ ), the maximum in August was $22^{\circ} \mathrm{C}$. After the power station began to operate winter temperature in 1959 was never below $6.5^{\circ} \mathrm{C}$; summer temperature in 1957 reached $26.5^{\circ} \mathrm{C}$ and exceeded slightly $27^{\circ} \mathrm{C}$ in 1959 (Raymont \& Carrie 1964).

As a result of such temperature increase "foreign" warm-water species settled and began to reproduce successfully. In Southampton harbour the bivalve mollusc Mercenaria (Venus) mercenaria from coastal waters of the New England region of North America's Atlantic coast appeared (Ansel. 1963, and others); in Marchwood and the neighbouring Calshot the australo-asiatic barnacle Elminius modestus established itself, its nauplii completely dominated the summer zooplankton of Marchwood and formed 40 to $50 \%$ of it in Calshot. A literature review (Mileikovsky 1965) shows that such dominance of cirripede nauplii in the summer plankton is very unusual for boreal waters where the majority of local cirripede species have an early spring period of mass liberation of nauplii (BARNES 1957, and others). The barnacle Balanus amphitrite which settled in Portsmouth harbour is widely distributed in tropical, subtropical and nearby temperate waters (STuBbrNGs \& Houghton 1964).

It is interesting to note that near Southampton $M$. mercenaria was absent outside the heated water district (ANSELL 1963), and that B. ampbitrite in a distance of a few miles from Portsmouth in the water of Chichester harbour, not heated by industrial wastes, was represented only by a small "pseudopopulation"' formed by the larvae carried here from the Portsmouth region and unable to reproduce (STubbings \& HovgHTON 1964).

In the Queen's Dock in Swansea (Wales), during the period from 1935 to November 1960 , the water was much warmer than the surrounding marine area because heated effluents were discharged into the dock from a nearby power station (annual water temperature amplitude: $14^{\circ}$ to $26^{\circ} \mathrm{C}$ in the dock; $3.7^{\circ}$ to $16.5^{\circ} \mathrm{C}$ near the dock in the sea). As a consequence many warm-water species immigrated; at the same time, in many local species the breeding season became more or less prolonged or began earlier than in all other regions of British littoral waters. The common boreal crab Carcinus maenas was no longer able to reproduce in the warmed up area because of too high water temperatures (the population in the dock was not only very small, but was also sterile and maintained by the settlement of larvae entering the dock from outside). C. maenas resumed reproduction (shedding of ova) in the dock only after a sharp decline of water temperature as a result of decreased power station activity after November 1960 (NAYLOR 1965a).

1 We proposed (Mileikovsky 1961b) to use V. N. BeKLemischev's term "pseudopopulation" for sterile populations of marine bottom invertebrates which are formed sometimes by some species outside of their main areals and which are maintained only because of arrival with currents of larvae in the areals of the species. 


\section{INFLUENCE OF WATER POLLUTION}

Human activities can also change the concentrations of chemical substances and of organic components. Such alterations, in turn, may again affect the breeding of bottom invertebrates. It is sufficiently known that with progressing pollution of littoral waters near large ports and seashore cities the bottom fauna of these waters becomes poorer because of the elimination of many species which are not able to reproduce under polluted conditions. At the same time the bottom fauna of such polluted waters becomes more specific because of the flourishing in these conditions of populations of a few species such as the polychaete Capitella capitata; examples were described in detail by R.EISH $(1955,1957 \mathrm{a}, \mathrm{b}, 1960,1961 \mathrm{etc}$.) in the littoral waters near the south California cities Los Angeles and Long Beach.

Rzhepishevsky (1963) discovered on the East Murman coast in the Dalneselenetzky fjord - polluted by sawdust from sawmill and sewage from cattle shed blooming of small flagellates and, stimulated by it, mass appearance of barnacle larvae Balanus balanoides, B. balanus and B. crenatus; both phenomena occurred a fortnight earlier (a period which barnacle nauplii which feed on diatoms, must exist without food and consequently spend their energy in vain) than in the nearby fjord Yarnishny in which the waters remained clean.

BREESE et al. (1963) discovered in a laboratory experiment that the sewage waters of a kraft-mill in Oregon were very effective in stimulating gamete shedding in $\mathrm{My}$ tilus californianus from the nearby shores. The authors were not able to determine the nature of chemical substance stimulating the shedding. However, they came to the conclusion that the critical concentration of this stimulating substance will not be high enough to stimulate gamete shedding under natural conditions in situ.

To this conclusion of BreEse et al. (1963) two considerations from our point of view can be added. Firstly, very near to the kraft-mill itself the concentration of the pollutant substances may exceed the critical value in restricted areas of the mussels' distribution; the spawning of this restricted groups may then stimulate the spawning of the rest of the population via the mechanisms described by GALTSOFF (1930) and others for Crassostrea virginica. Secondly, with the growth of the mill, or with the building of additional mills near it, the concentration of the effluent will increase and thus may become sufficiently high to cause the effects observed under laboratory conditions.

It must finally be mentioned that KALUGINA et al. (1967) have studied under laboratory conditions the influence of sewage and oil polluted water of the Novorossjiskaya Bay (collected at distances from 25 to $200 \mathrm{~m}$ from the point of discharge) on the pelagic larvae of some gastropods (not identified) and decapods (Diogenes pugilator and some prawns). They discovered that these larvae withstand the water pollution much better than such holoplanters as copepods Acartia clausi and Centropages kröyeri. These copepods were killed by the polluted water taken at the distance of $25 \mathrm{~m}$ from the point of discharge during the first two days. Decapod and gastropod larvae lived in the same water at least three days, while some specimens lived there even longer (10 days). 


\section{INFLUENCE OF SHIP ACTIVITIES}

Intensive ship movements in littoral waters may lead to considerable dynamical unrest and thus may influence, in some cases, the breeding and spawning of bottom invertebrates especially those sensitive to water movement swarming forms.

It was shown by Berkeley (1961) that near Nanaimo (British Columbia) syllid polychaete Odontosyllis phosphorea var. nanaimoensis (originally quite plentiful when swarming) have completely disappeared after the establishment in this region of regular ferry traffic and intensification of boat movements.

\section{INFLUENCE OF BIG RIVERS}

Big rivers are frequently used as transportation medium for various pollutants introduced by human activities. They can greatly affect areas far awey from the original point of waste disposal. This is particularly true if the river enters small littoral water bodies, lakes or semi-enclosed areas such as bays, lagoons, etc.

For example, the erecting of new powerful hydroelectric stations at the banks of the river Volga, linked to the river Don via the chanel "Volga-Don", has changed the volume of river water entering the Azov Sea and changed the salinity of this sea, thus influencing all components of its bottom fauna.

To a lesser degree, but evidently also sufficiently strong, the above mentioned stations must influence the poorer fauna of the North Caspian Sea which is better adapted to low salinities.

In such seas the influence of the components of human activities discussed above, e. g., heating, pollution and ship activities must be even more pronounced than at the shores of the fringing seas.

\section{GENERAL CONCLUSIONS}

The information presented above illustrates that human activities tend to alter the environmental conditions on marine shores and thus influence the breeding and spawning of nearshore bottom invertebrates. Because of the continuously progressing intensification of these activities man's influence on the breeding and spawning of littoral marine bottom invertebrates will also steadily grow in the years to come. This intensification of human influences will affect most severely the bottom faunas of inland and semi-enclosed shallow seas. No doubt, the North Sea, especially its shallow southern part, is to be included in this category.

The influence of human activities on the breeding and spawning of littoral bottom invertebrates and its biological consequences may be described as follows:

(1) Changes in time and seasonal pattern of spawning in local forms. In the cases of heating up the water, this may even lead to inhibition of spawning. 
(2) Creation of suitable conditions for breeding and spawning in local waters for immigrant species. (In temperate waters heated effluents may lead to immigration of tropical and subtropical forms.)

(3) Stimulation of gamete shedding outside the normal season and subsequent release of planktonic larvae in local species.

(4) Changes in the normal succession of appearance in local mero-plankton forms.

(5) Changes in the quantitative interrelations between different groups of pelagic larvae of bottom invertebrates leading to alterations in the quantitative- qualitative interrelations of the neritic planktonic biocoenoses as a whole.

Among the environmental factors determining the ecological dynamics of the breeding and spawning of marine bottom invertebrates the influence of human activities on sea shores, littoral waters and big rivers has thus far not been treated (THORSON 1946, 1950, 1952, Giese 1959, Mileikovsky 1961a, Kinne 1963, 1964). The data mentioned above, from our point of view (Mileikovsky 1965), forces us to draw the conclusion that in regard to the breeding and spawning of marine bottom invertebrates, living near the shores exploited and densely populated by men, the factor "human influence" must be taken into account among the most effective environmental factors. In fact, the human activities on such sea shores must be rated as one of the most important factors influencing the biology of littoral marine waters as a whole and must be discussed in detail in future text books on marine ecology.

\section{SUMMARY}

1. The influences of human activities on the breeding and spawning of marine littoral bottom invertebrates are discussed on the basis of information from literature and own results.

2. Human activities (e. g. heated effluents, chemical water pollution, ship activities, pollution of big rivers) modify living conditions and biological activities of bottom invertebrates in various ways; the major biological consequences are listed below under points 3 to 6 .

3. Human activities, especially local heating, may change time and seasonal pattern of spawning in local populations; in extreme cases spawning may be completely inhibited.

4. Heated effluents may provide suitable living conditions for tropical or subtropical species originally foreign to the area and thus change the species composition of the local ecosystem.

5. Human activities may stimulate gamete shedding outside the normal season.

6. Human activities may change the normal succession of local mero-plankton forms and thus alter quantitative and qualitative interrelations between different components of the biocoenosis.

7. The detrimental effects of human activities tend to be most severe in shallow, semi-enclosed areas. Consequently, the southern North Sea represents an area which deserves particular attention. 


\section{LITERATURE CITED}

Alfmov, N. N., 1959. On the methods of hydrobiological investigations for the sanitary evaluation of nearshore marine waters. [Russ.] Trudy vses. gidrobiol. Obshch. (Proc. AllUnion hydrobiol. Soc.) 9, 360-366.

ANSELL, A. D., 1963. Venus mercenaria L. in Southampton waters. Ecology 44, 396-397.

Barnes, $H ., 1957$. Processes of restoration and synchronization in marine ecology. The spring diatom increase and the "spawning" of the common barnacle, Balanus balanoides L. Année biol. 33, 67-85.

Berkeley, E., 1961. Swarming of the polychaete Odontosyllis phosphorea Moore, var. nanaimoensis Berkeley, near Nanaimo, B. C., Nature, Lond. 191, 1321.

Breese, W. P., Mrllemann, R. E. \& Dimick, R. E., 1963. Stimulation of spawning in the mussels, Mytilus edulis LinNaEus and Mytilus californianus ConRAD, by kraft-mill effluent. Biol. Bull. mar. biol. Lab., Woods Hole 125, 197-206.

Galtsoff, P. S., 1930. The role of chemical stimulation in the spawning reactions of Ostrea virginica and Ostrea gigas. Proc. natn. Acad. Sci. U.S.A. 16, 555-559.

GIEsE, A. C., 1959. Annual reproductive cycles of marine invertebrates. Ann. Rev. Physiol. 21, 547-576.

Kalugina, A. A., Milovidova, N. J., Sviridova, J. V. \& Uralskaxa, J. V., 1967. Effect of pollution on marine organisms of Novorossyisky Bay of the Black Sea. [Russ.] Gidrobiol. Zh., Kiev $3(1), 47-53$.

KINNE, O., 1963. The effects of temperature and salinity on marine and brackish water animals. I. Temperature. Oceanogr, mar. Biol. Ann. Rev. 1, 301-340.

- 1964. The effect of temperature and salinity on marine and brackish water animals. II. Salinity and temperature-salinity combinations. Oceanogr. mar. Biol. Ann. Rev. 2, 281-339.

LoOSANOFF, V. L., 1959. Some effects of pesticides on marine arthropods and mollusks. In: Biological problems of water pollution. Transactions of the 2nd seminar, held April 20-24, 1959 at Cincinnati, Ohio. Comp. by C. M. Tarzwell. U. S. Dpt of Health Education and Welfare, R. A. Taft Sanitary Engineering Center, Cincinnati, Ohio, 285 pp. (Tech. Rep. W 60-3).

LYN, W. R. \& YANG, WoN TAK, 1960. The ecological effects of sewage in Biscayne Bay. Oxygen demand and organic carbon determinations. Bull. mar. Sci. Gulf Caribb. 10, 491-509.

McNulty, J. K., Reynolds, E. S. \& Miller, S. M., 1959. Ecological effects of sewage pollution in Biscayne Bay, Florida: distribution of coliform bacteria, chemical nutrients, and volumes of zooplankton. In: Biological problems of water pollution. ... [Bibliogr. details s. LooSANOFF.]

Mrleixovsky, S. A., 1960. The effect of periodicity in the spawning of littoral and uppersublittoral invertebrates endowed with pelagic development on the composition and biology of neritic planktonic biocoenoses in the White Sea and other seas. [Russ.] Dokl. Akad. Nauk SSSR 134, 980-983.

- 1961a. Some problems on the reproductive ecology of marine bottom invertebrates with pelagic development. Trudy murmansk. morsk. biol. Inst. 3 (7). (Engl. transl. with Fisheries Laboratory. Ministry of Agriculture, Fisheries and Food. Lowestoft, Trans. N. S. 8.)

- 1961b. Character and nature of deep-water populations of eurybathic benthic forms of invertebrates with pelagic larvae taking as an example the polychaet Euphrosyne borealis Oersted, 1843 from the North Atlantic. Okeanologija 1, 679-687. (Engl. transl.: Deep Sea Res. 9, 531-537.)

- 1965. The larvae (mainly of Polychaeta and Gastropoda) and spawning ecology of marine bottom invertebrates with pelagic development on the examples of Barentz, White, Norwegian Seas and Gulf Stream. [Russ.] Diss. Institute of Oceanology, USSR Academy of Sciences, Moscow.

Mironov, O. G., 1966. Some problems of marine sanitary hydrobiology. [Russ.] Gidrobiol. Zhurn. $2(6), 72-80$. 
Naytor, E., 1965a. Biological effects of a heated effluent in docks at Swansea. Proc. zool. Soc. Lond. 144, 253-268.

- 1965b. Effects of heated effluents upon marine and estuarine organisms. Adv. mar. Biol. 3, 63-104.

Raymont, J. E. G., Carrie, B. G. A., 1964. The production of zooplankton in Southampton waters. Int. Revue ges. Hydrobiol. 49, 185-232.

Reish, D. J., 1955. The relation of polychaetous annelids to harbour pollution. Publ. Hlth. Rep. Wash. 70, 1168-1174.

- 1957a. Effect of water pollution on marine life. Ind. Wastes 1957 (Sept.-Oct.), 114-118.

- 1957b. The relationship of the polychaetous annelid Capitella capitata (FABricius) to waste discharges of biological origin. In: Biological problems of water pollution ... (Bibliogr. details s. LoosAnOFF) 195-200.

- 1960. The use of marine invertebrates as indicators of water quality. In: Waste disposal in the marine environment. Ed. by E. A. Pearson. Pergamon Press, Oxford, 92-103.

- 1961. The use of sediment bottle collector for monitoring polluted marine waters. Calif. Fish Game 47, 261-271.

RzhepishevsKy, I. K., 1963. Propagation of barnacles-balanids on the East Murman coast. (Russ.) Diss. Dalnie Zelentzi, Murman. Institute of Marine Biology Academy of Sciences of the USSR, Murmansk.

Stroganov, N. S., 1964. Chemization and the problems of water toxicology. (Russ.) Zool. Zh. 43, 1737-1752.

Stubings, H. G. \& Houghton, D. R., 1964. The ecology of Chichester harbour, S. England, with special reference to some fouling species. Int. Revue ges. Hydrobiol. 49, 233-280.

Thorson, G., 1946. Reproduction and larval development of Danish marine bottom invertebrates with special reference to planktonic larvae of the Sound (Øresund). Meddr. Kommn. Danm. Fisk.-og Havunders. (Ser. Plankton) 4, 1-523.

- 1950. Reproductive and larval ecology of marine bottom invertebrates. Biol. Rev. 25, 1-45.

- 1952. Zur jetzigen Lage der marinen Bodentier-Ókologie. Zool. Anz. (Suppl. Bd) 16, 270-327.

Yakovenko, V. A., 1959. The medical oceanography. Sanitary defence of the nearshore zone of the sea. (Russ.) State Medical Publ. House of Ukrainian SSR, icv.

\section{Discussion (by correspondence) following the paper by MILEIKovsKY}

Simpson: In relation to the speaker's remarks about the development of a population of Mercenaria mercenaria in the warm water at the head of the Southampton water I would like to make a few comments. This estuary is so heavily polluted with sewage that it is one of the few estuaries around England where edible molluscs may not be taken directly for food, even with cleansing before sale. Also this estuary is heavily polluted by oil from the many ships that use this port from an oil refinery. In spite of this, the population of Mercenaria mercenaria is the basis of an important fishery for export. The clams are relaid in a clean estuary for two weeks before sale.

MrLeikovsky: I must thank Dr. Simpson for this additional information. From my point of view this is a good argument for initiating special studies on the general and reproductive biology of $M$. mercenaria (and similar populations) in connection with the possible effects on them of different kinds of human activities on the shore and in the inshore waters. Such studies will be important from a commercial point of view.

KINNE: In regard to laboratory studies devoted to the problem of marine pollution a crucial point is the question: to what extent can they serve as a sound basis for predicting consequences of pollution in situ? Your review is based on both, laboratory and field studies. Would you care to comment on this important point? 
MrLkerkovsky: In some harbours, ports and parts of inshore zones, where volume and kind of pollutions are known for many successive years, we can predict, in general, for a few years ahead the composition and standing stock of the bottom fauna and flora. I think that, with the growing of our knowledge in this field, we shall come to a special system for predicting the consequences of any kind of pollution on biological processes in any type of inshore water bodies. But before this, of course, a very large amount of work must be done. 